\title{
Stosunki egipsko-syryjskie po 2011 roku
}

\section{Wstęp}

W najnowszej historii Bliskiego Wschodu rok 2011 stanowi cezurę czasową wyznaczającą granicę pomiędzy okresem sprzed i po tzw. Arabskiej Wiośnie. W ciągu zaledwie kilku miesięcy procesy rewolucyjne wstrząsnęły regionem. Doprowadziły do obalenia wieloletnich rządów (Egipt, Jemen, Libia, Tunezja), wywołały konflikty zbrojne (Jemen, Libia, Syria), a przede wszystkim zdestabilizowały region Bliskiego Wschodu i przyczyniły się do wzrostu roli ekstremistów muzułmańskich. Wszystkie powyższe procesy wpłynęły na reorientację polityki zagranicznej poszczególnych państw regionu zarówno na skutek zmiany władz jak i uwarunkowań międzynarodowych.

Niniejszy artykuł traktować będzie o relacjach pomiędzy Arabską Republiką Egiptu a Syryjską Republiką Arabską. Niniejsze dwa podmioty od wieków stanowią rdzeń regionu bliskowschodniego, będącego od tysiącleci jednym z kluczowych punktów m.in. pod względem geostrategicznym. Relacje pomiędzy nimi w przeszłości często decydowały o losach całego regionu. Dlatego analiza stosunków pomiędzy Egiptem a Syrią w obliczu destabilizacyjnych procesów tzw. Arabskiej Wiosny może być pomocna w zrozumieniu najnowszych uwarunkowań sytuacji w regionie Bliskiego Wschodu.

Problemem badawczym artykułu jest analiza i wyjaśnienie relacji egipsko-syryjskich po 2011 r., w kontekście wydarzeń i procesów mających miejsce w świecie arabskim w tym okresie. Przywołana cezura czasowa znajduje uzasadnienie w tym, że Arabska Wiosna zapoczątkowała nowy okres w dziejach Bliskiego Wschodu jak również przewartościowała relacje syryjsko-egipskie.

Hipotezy artykułu brzmią następująco:

- Egipt i Syrię łączą więzi historyczne mające swój początek we wczesnej starożytności, gdy zostały one połączone szlakami handlowymi. 
Następnie obydwa kraje ulegały podbojom oraz wpływom mocarstw by w końcu na fali ruchów tożsamościowych i narodowowyzwoleńczych osiągnąć niepodległość.

- Oba państwa stały się areną procesów związanych z tzw. Arabską Wiosną, które je zdestabilizowały. Gdy w Egipcie do władzy doszło Bractwo Muzułmańskie, kraj ten zerwał poprawne wówczas stosunki z pogrążającą się w wojnie Syrią oraz otwarcie wspierał rebelię.

- Gdy po kolejnym przewrocie w Egipcie do władzy powróciło wojsko, rozpoczął się powolny proces normalizacji stosunków pomiędzy oboma państwami. Wpływ na to miało także powstanie samozwańczego Państwa Islamskiego, które stało się największym zagrożeniem dla obu krajów.

- Jednak pełne zbliżenie Egiptu i Syrii było utrudnione przez relacje obu państw $\mathrm{z}$ innymi aktorami regionalnymi. Zdestabilizowany dwoma przewrotami Egipt pozostawał w sojuszu z Arabią Saudyjską oraz Stanami Zjednoczonymi, będącymi wrogami Syrii. Analogicznie Iran oraz Hezbollah to sojusznicy Syrii, a jednocześnie podmioty skonfliktowane z Egiptem. Diametralnie różne było również podejście obu państw do Izraela. Niewyjaśniona jak dotychczas jest również kwestia zawieszonego w 2011 r. członkostwa Syrii w Lidze Arabskiej. Mimo tych czynników, utrudniających powrót do dobrych relacji wzajemnych panujących przed 2011 r., polityka Egiptu prezydenta as-Sisiego postawiła to państwo poza szeregiem regionalnych wrogów Syrii, w którym niewątpliwie się znajdowało w okresie rządów Bractwa Muzułmańskiego.

Artykuł jest podzielony na cztery części. Część pierwsza stanowi historyczne tło analizy. Zostaną w niej przedstawione wspólne dzieje Egiptu i Syrii, które sięgają tysiącleci przed arabizacją oraz islamizacją tych terenów. Głównym punktem ciężkości w historii relacji wzajemnych będzie XX wiek, kiedy ze względu na procesy kolonialne, a następnie rozwój ideologii panarabskiej, antykolonializm i utworzenie Izraela, znaczenie obu państw oraz relacji między nimi zwiększyło się w znacznym stopniu. Część druga odpowie na pytanie, w jaki sposób tzw. Arabska Wiosna wpłynęła na relacje Egiptu i Syrii, w jaki sposób się one zmieniały oraz jaki był stosunek rządzącego Egiptem od 2012 r. Bractwa Muzułmańskiego wobec 
konfliktu syryjskiego. Następnie w części trzeciej motywem przewodnim będzie wpływ upadku rządów Bractwa Muzułmańskiego w Egipcie na relacje obu państw. Dodatkowym aspektem będzie eskalacja napięcia w Syrii, w tym rola samozwańczego Państwa Islamskiego. W tej części zostaną przedstawione czynniki warunkujące zbliżenie między oboma aktorami jak również pozostające kwestie sporne i nierozstrzygnięte. Część z nich determinowana jest przez wpływ podmiotów trzecich co zostanie poddane analizie w części czwartej. Zostanie w niej wyjaśnione jak na relacje wzajemne wpływają stosunki obu państw z wybranymi aktorami przede wszystkim regionalnymi, ale również mocarstwami oraz podmiotami pozapaństwowymi.

Artykuł powstał w oparciu o analizę literatury historycznej oraz współczesnej dotyczącej obydwu państw i regionu Bliskiego Wschodu, a także na podstawie artykułów prasowych traktujących o najnowszych wydarzeniach determinujących relacje egipsko-syryjskie i pochodzących z różnorodnych źródeł od New York Times, przez Guardiana, Reutera po portale z Egiptu (Al-Ahram), Syrii (Syrian Arab News Agency) oraz Izraela (Haaretz). Oprócz metody analizy treści oraz metody historycznej zastosowano metodę systemową, pozwalającą odpowiedzieć na pytanie, w jaki sposób aktorzy regionalni i pozaregionalni kształtują stosunki egipsko-syryjskie.

Zadaniem niniejszego opracowania jest próba zrozumienia najnowszych uwarunkowań kształtujących wydarzenia na Bliskim Wschodzie. Brak w literaturze pozycji traktującej o relacjach pomiędzy tymi dwoma państwami. Oczywiście przy okazji opisywania bliskowschodnich procesów politycznych poruszano kwestie tych relacji. Rafał Ożarowski opisywał uwarunkowania prowadzące do utworzenia Zjednoczonej Republiki Arabskiej w 1958 r. oraz jej rozpadu trzy lata później ${ }^{1}$; Albert Hourani poruszył kwestie rozbieżności politycznych pomiędzy Egiptem a Syrią podczas wojny październikowej (w 1973 r.) przeciwko Izraelowi, co bezpośrednio przełożyło się na ich porażkę2. Szymon Niedziela dostrzegł z kolei różne podejście obu aktorów do izraelskiej operacji „Płynny Ołów” wymierzonej w Hamas w $2009^{3}$ r. Mimo tych ważnych wzmianek brak opra-

1 R. Ożarowski, Ideologia na Bliskim Wschodzie, Gdańsk 2006, s. 64-76.

2 A. Hourani, Historia Arabów, tłum. oprac. zbior. Gdańsk 1995, s. 413-414.

3 Sz. Niedziela, Konflikty i napięcia w świecie arabskim, Warszawa 2012, s. 113. 
cowania dotyczącego nie tylko relacji Egiptu i Syrii po 2011 r., ale również kompleksowego opracowania jak przez kolejne epoki historyczne układały się wzajemne stosunki obu krajów.

\section{Rys historyczny stosunków egipsko-syryjskich}

Na wyjątkowy charakter relacji egipsko-syryjskich wpływ mają między innymi uwarunkowania historyczne. Choć to historia najnowsza, obejmująca dzieje obu państw w XX w., była punktem kulminacyjnym ich wspólnej drogi, to jej początek wykracza daleko wstecz nawet przed powstanie islamu i arabizację tych terenów. Pierwszą wzmiankę dotyczącą połączenia losów obu aktorów datuje się na poł. XVI w. p.n.e., kiedy ówczesny Egipt inkorporował ziemie należące dziś do Syrii ${ }^{4}$. W kolejnych stuleciach tereny obu państw podbijane były przez Hellenów, Rzymian i Bizantyjczyków. W VII w. n.e. wraz z powstaniem islamu rozpoczęły się procesy, które aż po dziś dzień mają wpływ na losy nie tylko obu tytułowych podmiotów, ale i na cały region Bliskiego Wschodu. Armie arabskie pod wodzą kalifa Umara ibn al-Chattaba rozpoczęły ekspansję z Półwyspu Arabskiego we wszystkich kierunkach. Ze względu na swoje położenie Egipt i Syria stały się jednymi z pierwszych celów podbojów szerzących nową religię. Damaszek został zdobyty w 635 r., a Aleksandria osiem lat później ${ }^{5}$. Od tej pory ziemie obu dzisiejszych państw ulegały procesom arabizacji oraz islamizacji.

W kolejnych wiekach Egipt i Syria znajdowały się wspólnie pod panowaniem dynastii Umajjadów, Abbasydów, Fatymidów oraz Ajjubidów. Mimo procesów islamizacji zarówno na terenie Egiptu jak i Syrii zachowało się przywiązanie do dorobku kulturowo-cywilizacyjnego epoki przedislamskiej. Jest to specyficzna cecha obu państw, co świadczy o kultywowaniu własnej historii jako kolebki cywilizacji.

Panowanie Arabów zakończyła ekspansja dawnych tureckich niewolników - Mameluków. Dwie dynastie (Bahryci i Burdżyci) panowały nad Egiptem i Syrią od 1250 roku6. W 1517 r. panowanie Mameluków zostało

4 J. Żebrowski, Dzieje Syrii. Od czasów najdawniejszych do wspótczesności, Warszawa 2006, s. 43.

5 M. Dziekan, Dzieje kultury arabskiej, Warszawa 2008, s. 180.

6 A.L. As-Sajjid Marsot, Historia Egiptu. Od podboju arabskiego do czasów wspótczesnych, tłum. Z. Landowski, Warszawa 2009, s. 52. 
przerwane przez ekspansję Imperium Osmańskiego. Z dawnego państwa mameluckiego utworzono trzy prowincje osmańskie: Aleppo, Damaszek oraz Kair ${ }^{7}$. Mimo że Turcy podbili znaczną część Bliskiego Wschodu, to Egipt i Syria stanowiły ekonomiczny i kulturowy rdzeń mocarstwa. Albert Hourani zauważył, że to te prowincje najobficiej zasilały budżet Imperium $^{8}$. Ponadto były atrakcyjne geostrategicznie ze względu na krzyżowanie się szlaków handlowych. Poza tym, z Egiptu i Syrii ruszały liczne pielgrzymki do Mekki, co było ważne dla Turków roszczących sobie pozycję panislamskiego imperium.

Choć obecność Turków na ziemiach arabskich uznawana była przez ludność miejscową za okupację, to jednak wg Alberta Houraniego wydzielenie arabskich prowincji Imperium i nadanie im znacznego stopnia samodzielności niwelowało niechęć wobec ciemiężycieli ${ }^{9}$. Nie bez znaczenia było również to, że Turcy uchodzili za reprezentanta islamu. Sytuacja zmieniła się po roku 1798, kiedy francuska inwazja na Egipt otworzyła drogę do penetracji regionu przez zachodnie mocarstwa kolonialne - Wielką Brytanię i Francję. Geostrategiczna atrakcyjność regionu, znacznie zwiększona po otwarciu Kanału Sueskiego w 1869 r., spowodowała stały wzrost obecności Europejczyków na terenie Egiptu i Syrii. Jednak miejscowi zaczęli wyrażać sprzeciw wobec kolonizacji. W 1833 r. Ibrahim Pasza jako namiestnik Imperium Osmańskiego w Egipcie inkorporował prowincje syryjskie, jednak wspólnymi wysiłkami Wielkiej Brytanii i Turcji został zmuszony do wycofania się z nich ${ }^{10}$.

W kolejnych dziesięcioleciach proces rozbudzania tożsamości narodowej i aspiracji wyzwoleńczych przyspieszył i w Egipcie i w Syrii. Od początku XX wieku Imperium Osmańskie ulegało osłabieniu, ale z kolei coraz większą pozycję w regionie zapewniały sobie Wielka Brytania i Francja. W przeciwieństwie do Turków z którymi Arabów łączył islam, Europejczycy byli jednoznacznie uważani za ciemiężycieli. Takie postrzeganie mocarstw pogłębiło się w kolejnych latach. W 1916 r. oba mocarstwa kolonialne zawarły pakt Sykes-Picot o podziale ziem upadającego Impe-

7 Ibidem, s. 59.

8 A. Hourani, op.cit., s. 228-229.

9 Ibidem, s. 309.

10 A.L. As-Sajjid Marsot, op.cit., s. 90-93. 
rium Osmańskiego ${ }^{11}$. Egipt znalazł się w orbicie wpływów brytyjskich natomiast Syria - francuskich. Rok później Wielka Brytania ogłosiła Deklarację Balfoura o możliwości powstania państwa żydowskiego w Palestynie, co było nie do przyjęcia dla Arabów, w tym dla Egiptu i Syrii, pomiędzy którymi znajdowała się Palestyna.

Nowy etap w relacjach egipsko-syryjskich rozpoczął się w latach 40 . XX w. W 1941 r. Francja proklamowała niepodległość Syrii. W tym czasie Egipt był już formalnie niepodległy od 19 lat. W 1945 r. oba państwa zostały członkami założycielami Ligi Państw Arabskich ${ }^{12}$. Trzy lata później gdy Brytyjczycy opuścili Palestynę, a ONZ zatwierdziła jej podział na państwo arabskie i żydowskie, Izrael proklamował niepodległość. Według Łukasza Fryderka to wydarzenie otworzyło nowy rozdział w dziejach arabskich państw Bliskiego Wschodu - od tej pory walka z Izraelem stała się wyznacznikiem ich polityki zagranicznej oraz elementem tożsamości ${ }^{13}$. Pozwoliło to na rozwój sojuszu pomiędzy Egiptem i Syrią, które znalazły się na pierwszej linii walki.

Rozwój stosunków pomiędzy oboma państwami determinowany był również podobnymi procesami ideologicznymi i politycznymi. Zarówno Egipt jak i Syria są kolebkami odrodzenia tożsamości, aspiracji niepodległościowych, ruchów antykolonialnych oraz arabskiego socjalizmu i arabskiego nacjonalizmu - nurtów, które Marek Dziekan określił mianem koła zamachowego, które zaważyło na współczesnym kształcie świata arabskiego $^{14}$. W 1952 r. zamach stanu w Egipcie, przeprowadzony przez Wolnych Oficerów, wyniósł do władzy Dżamala Abd an-Nasira. W tym czasie w Syrii na popularności zyskiwała Partia Baas, utworzona w 1940 r. m.in. przez Michela Aflaka ${ }^{15}$.

11 Pakt zawdzięcza swą nazwę nazwiskom Ministrów Spraw Zagranicznych Wielkiej Brytanii i Francji. Zdaniem M. Dziekana podział stref wpływów był sztucznym nakreśleniem granic pomiędzy państwami, zignorowano m.in. tak ważne w arabskiej tradycji związki plemienne, zob. więcej: M. Dziekan, op.cit., s. 306.

12 T. Fryzel, Liga Państw Arabskich, Warszawa 1981, s. 28.

13 Ł. Fyderek, Pretorianie i technokraci w reżimie politycznym Syrii, Kraków 2011, s. 206.

14 M. Dziekan, op.cit., s. 307-308.

15 Oprócz Michela Aflaka współzałożycielami Partii Baas byli Salah ad-Din al-Bitar oraz Zaki al-Arsuzi. W 1952 r. Baas połączono z Arabską Partią Socjalistyczną Akrama alHouraniego dzięki czemu powstała Socjalistyczna Partia Odrodzenia Arabskiego, zob więcej: Ł. Fyderek, op.cit., s. 132. 
Na bazie nastrojów antykolonialnych wspólnie odrzucono inicjatywy państw zachodnich mających na celu uzależnienie od siebie państw Trzeciego Świata oraz tworzenie antyradzieckich sojuszy. W 1955 r. Egipt i Syria odmówiły przystąpienia do Paktu Bagdadzkiego ${ }^{16}$. Rok później, gdy Wielka Brytania, Francja i Izrael dokonały agresji na Egipt, Syria potępiła napaść i poparła Kair, jednak jedynie środkami politycznymi. Te wydarzenia utwierdziły oba państwa w antyzachodnim nastawieniu i pomogły rozwinąć współpracę ze Związkiem Radzieckim na polu militarnym oraz ekonomicznym ${ }^{17}$.

Egipt i Syria jako jedyne państwa urzeczywistniły ideę zjednoczenia państw arabskich. Unia pomiędzy nimi zawarta została 1 lutego $1958 \mathrm{r}$. w Kairze, gdzie proklamowano powstanie Zjednoczonej Republiki Arabskiej ${ }^{18}$. Prezydentem nowego państwa został Dżamal Abd an-Nasir, a syryjskie partie polityczne (w tym Baas) zostały zlikwidowane. Syria jako strona słabsza w pakcie zgodziła się na Unię z kilku względów. Według Rafała Ożarowskiego oprócz bliskości ideologicznej elity syryjskie chciały w ten sposób zatrzymać rosnące wpływy komunistów, a ponadto powodem były złe relacje z Turcją oraz chęć stworzenia przeciwwagi dla haszymidzkiej unii Iraku i Jordanii pod patronatem Wielkiej Brytanii ${ }^{19}$. Mimo że czynniki te stanowiły ważną motywację, strona syryjska świadoma była różnic politycznych z Egiptem. Dlatego o zawarciu Unii przesądził autorytet, jakim cieszył się an-Nasir wśród ludności arabskiej w całym regionie. Odrzucenie propozycji przyłączenia się do przywódcy Egiptu mogłoby skutkować krytyką syryjskich elit przez zwykłych obywateli. Ze względu na wyżej wymienione różnice oraz jednoznaczną dominację Egiptu, ZRA rozpadła się po trzech latach. Mimo próby uformowania podobnych unii w przyszłości, żadna już nie została zrealizowana ${ }^{20}$.

16 Pakt Bagdadzki był inicjatywą Wielkiej Brytanii, mającą na celu utworzenie sieci sojuszy antyradzieckich. Do Paktu przyłączyły się Iran, Irak, Pakistan i Turcja.

17 A. Hourani, op.cit., s. 374.

18 R. Ożarowski, op.cit., s. 67.

19 Ibidem, s. 65-66.

20 Jedną z takich prób była proklamacja Federacyjnej Republiki Arabskiej w 1973 r. w Damaszku. Na FRA składać się miały Egipt, Libia i Syria. Zob więcej: Ibidem, s. 82. 
Mimo pierwszej tak poważnej rysy we współczesnych relacjach obu państw, sojusz wciąż trwał. Jak zostało już wcześniej wspomniane głównym celem obu państw była walka z Izraelem. W 1967 r. doszło do wojny sześciodniowej i oba państwa poniosły dotkliwe straty ludzkie, materialne oraz terytorialne - Egipt stracił Półwysep Synaj, a Syria Wzgórza Golan. W 1970 r. w obu krajach zmienili się liderzy. W Egipcie po śmierci an-Nasira władzę przejął Anwar as-Sadat, a w Syrii udany zamach stanu wyniósł do władzy Hafiza al-Asada. Sojusz obu państw przyczynił się do zainicjowania nowej wojny z Izraelem w 1973 r. Celem wojny październikowej było odzyskanie terenów utraconych sześć lat wcześniej. Plan ten mimo dobrej postawy wojsk obu krajów nie powiódł się - jak uważa Albert Hourani, zdecydowały różnice polityczne i partykularne interesy, przez które nie koordynowano działań po pierwszej udanej fazie wojny ${ }^{21}$. W $1979 \mathrm{r}$. Egipt i Izrael zawarły układ pokojowy w Camp David. W ten sposób Syria utraciła głównego sojusznika w konfrontacji z Izraelem i wspólnie z innymi państwami arabskimi zerwała stosunki dyplomatyczne z Egiptem. W kolejnych latach doszło do kolejnego wydarzenia, które poróżniło Egipt i Syrię. W 1980 r. wybuchła wyniszczająca, ośmioletnia wojna pomiędzy Iranem a Irakiem. Oba państwa poparły przeciwne strony - Egipt (jak większość państw Arabskich) wspierał Irak, a Syria - Iran.

Do odprężenia na linii Egipt - Syria doszło w 1990 r. gdy oba państwa odnowiły stosunki dyplomatyczne oraz wzięły udział w wojnie przeciwko Irakowi. W następnych latach Egipt był jednym z mediatorów w rokowaniach syryjsko-izraelskich. Gdy po śmierci Hafiza al-Asada w 2000 r. prezydentem został jego syn - Baszszar, stosunki obu państw ulegały dalszej poprawie. Decydowała o tym również postawa egipskiego prezydenta, Hosniego Mubaraka, który stawiał sobie za cel być w jak najlepszych relacjach z państwami arabskimi. W 2003 r. oba kraje potępiły amerykańską agresję na Irak ${ }^{22}$.

Mimo zbliżenia i dobrych relacji w XXI w., wciąż pozostawały kwestie dzielące oba państwa. Taką kwestią była bliska współpraca Egiptu ze Stanami Zjednoczonymi oraz poprawne relacje z Izraelem. Z kolei sojuszni-

\footnotetext{
21 A. Hourani, op.cit., s. 413.

22 Ł. Fyderek, op.cit., s. 227.
} 
kami Syrii był Iran oraz organizacje, na które Egipt nie patrzył przychylnie - Hezbollah i Hamas. Uwydatniło się to m.in. w 2009 r. podczas izraelskiej operacji w Strefie Gazy przeciwko Hamasowi. Operacja „Płynny Ołów” wywołała różne postawy rządów syryjskiego i egipskiego. Pierwszy z nich poparł Hamas, a drugi (co prawda nieotwarcie) - Izrael $^{23}$.

Mimo punktów spornych, w 2010 r. relacje egipsko-syryjskie pozostawały dobre. Kształtowały się one przez tysiące lat wspólnej drogi przez historię. Zamieszkiwane przez wiele różnych ludów, podbijane, okupowane, następnie inicjujące procesy tożsamościowe i wyzwoleńcze, a w końcu szukające swojej drogi w ramach sojuszu niepodległych państw, Egipt i Syria przebyły długą drogę przez kolejne epoki historyczne aż po pierwsze dziesięciolecie XXI w. Mimo że apogeum dobrych relacji pomiędzy nimi nastąpiło w okresie powstania ZRA, to w 2010 r. oba państwa weszły w dobrych stosunkach. Jednak pod koniec tego roku na Bliskim Wschodzie rozpoczął się proces, który zmienił oblicze regionu oraz państw, które w nim się znajdują, a także relacje między nimi panujące.

\section{Konsekwencje wydarzeń związanych z tzw. Arabską Wiosną na relacje Egiptu i Syrii}

Przełom roku 2010 i 2011 rozpoczął procesy związane z tzw. Arabską Wiosną. Przyczyna zjawiska nie jest do końca znana. Istnieją teorie mówiące o tym, że były to fale spontanicznych demonstracji przeciwko skorumpowanym reżimom sprawującym władzę od wielu lat. Twierdzenie takie zostało powszechnie przyjęte, jednak jak zwraca uwagę Frederic Pichon, ma ono charakter powierzchowny. Uważa on, że do rozruchów mogło dojść z inicjatywy sił zewnętrznych m.in. Arabii Saudyjskiej i Kataru, finansujących powstawanie i działalność meczetów szerzących treści salafickie - radykalne i wymierzone we władze państw, na terenie których się one znajdowały $^{24}$. Z kolei Henry Kissinger uważa, że demokracja o którą wal-

23 Mimo że Egipt popierał dążenia Palestyńczyków do utworzenia własnego państwa, to pozostawał w konflikcie z operującym w Strefie Gazy Hamasem. Dlatego działania podejmowane przez Izrael przeciwko tej organizacji były korzystne dla Kairu. Jednak otwarte poparcie werbalne działań Izraela nie wchodziło w grę ze względu na możliwość potępienia w świecie arabskim. Zob. więcej: Sz. Niedziela, op.cit., s. 113.

24 F. Pichon, Syria. Porażka strategii Zachodu, tłum. G. Majcher, Warszawa 2015, s. 35. 
czyła opozycja była jedynie środkiem do przejęcia władzy przez podmioty niepopierające demokracji ${ }^{25}$.

Procesy związane z tzw. Arabską Wiosną dotknęły zarówno Egipt jak i Syrię, jednak żadne z tych państw nie było ich prekursorem ${ }^{26}$. W Egipcie mimo początkowego oporu, Hosni Mubarak ustąpił ze stanowiska prezydenta, a władzę przejęła Najwyższa Rada Sił Zbrojnych ${ }^{27}$. W Syrii protesty rozpoczęły się 15 marca 2011 r., dopiero miesiąc po ustąpieniu egipskiej głowy państwa, jednak władze w tym kraju nie ustąpiły. Opozycja zachęcona wsparciem ze strony monarchii Zatoki Perskiej oraz państw Zachodu chwyciła za broń, co doprowadziło do wojny. Tymczasem do końca czerwca 2012 r. Bractwo Muzułmańskie poprzez demokratyczne wybory zdobyło pełnię władzy w Egipcie ${ }^{28}$. W takich okolicznościach stosunki egipsko-syryjskie musiały ulec przewartościowaniu.

Celem zrozumienia nowych uwarunkowań w relacjach pomiędzy Egiptem a Syrią, należy wyjaśnić, jakie relacje miała Syria z Bractwem Muzułmańskim, zanim doszło ono do władzy w Egipcie. Organizacja powstała w 1928 r. w Egipcie i w kolejnych latach zaczęła rozszerzać swoją działalność na dalsze tereny. W latach 30. XX w. dotarła do Syriii ${ }^{29}$. Rok po dojściu do władzy Partii Baas w tym kraju organizacja została zdelegalizowana. Powodem konfliktu była rozbieżność ideologiczna. Syria była laicką, socjalistyczną republiką, a Bractwo było przedstawicielem radykalizmu muzułmańskiego. W kolejnych latach prowadziło ono na terenie Syrii działalność podziemną oraz terrorystyczną i zainicjowało powstanie w mieście Hama w 1982 r., które zostało krwawo stłumione. Dotychczasowe relacje Syrii z Bractwem Muzułmańskim pozwalały przypuszczać, że po $2011 \mathrm{r}$. dojdzie do regresji relacji pomiędzy rządzonym przez tę organizację Egiptem a Syrią.

25 H. Kissinger, Porzadek światowy, tłum. M. Antosiewicz, Wołowiec 2016, s. 121.

26 Masowe protesty w Egipcie rozpoczęły się 25 stycznia 2011 r., a w Syrii 15 marca tego samego roku. Przed 25 stycznia demonstracje rozpoczęły się w Tunezji, Algierii, Jordanii, Jemenie, Mauretanii oraz Omanie. Zob więcej: J. Zdanowski, Bliski Wschód 2011: bunt czy rewolucja?, Kraków 2011, s. 12-19.

27 Ibidem s. 19.

28 A. Bakr, Egypt's Mursi says opposes foreign intervention in Syria, 26.09.2012, Reuters, https://mobile.reuters.com/article/amp/idUSBRE88P1BC20120926.

29 J. Zdanowski, op.cit., s. 177. 
Mimo że Syria zadeklarowała chęć utrzymania pozytywnych relacji z Egiptem, to w listopadzie 2011 r. ten ostatni poparł projekt zawieszenia Syrii w Lidze Państw Arabskich ${ }^{30}$. Z kolei w lutym 2012 r. Egipt wycofał swojego ambasadora z Damaszku ${ }^{31}$. Pod koniec tego samego roku egipskie linie lotnicze Egyptian Air zawiesiły loty do Syrii ${ }^{32}$. Wroga stała się również retoryka nowych władz w Kairze.

Gdy Muhammad Mursi został prezydentem, zaczął wzywać władze w Damaszku do ustąpienia. Nazywał je opresyjnymi i jednocześnie otwarcie popierał rebelie. Jednak pierwsza faza rządów Mursiego wiązała się z priorytetem działań dyplomatycznych. Mursi dążył do powstania grupy kontaktowej ws. Syrii, której deklarowanym celem miała być deeskalacja napięć. W skład grupy oprócz Egiptu miałyby wejść Arabia Saudyjska, Iran i Turcja ${ }^{33}$. Propozycja została ostro skrytykowana przez Syrię i ostatecznie nie wprowadzono jej w życie. Jednocześnie Egipt odrzucał inicjatywy (m.in. Kataru) wzywające do zewnętrznej interwencji w Syrii.

Rok 2013 oznaczał dalszą eskalację konfliktu w Syrii, która nie była już wojną domową, a stała się wielowymiarowym konfliktem, w który były zaangażowane państwa regionu, aktorzy pozapaństwowi oraz mocarstwa światowe. Każde z nich szukało dla siebie korzyści z udziału w syryjskiej wojnie. Tymczasem rebelianci zaczęli przejmować coraz większe obszary kraju. Rządzony przez Bractwo Muzułmańskie Egipt był jednym z państw, które zamierzały osiągnąć w tej wojnie korzystne dla siebie cele. Należy przy tym dodać, że formacja rządząca Egiptem od 2012 r. była również uczestnikiem wojny w Syrii.

30 b.d.a., In Advance Of Arab League Summit In Jordan, Calls In Arab Countries To Reinstate Syria's League Membership; Syrian Writers Reject Calls For Reinstatement, Saying Syria Will Return Only If Arab League Apologizes To It, 23.03.2017, Memri, https://www.memri. org/reports/advance-arab-league-summit-jordan-calls-arab-countries-reinstate-syriasleague-membership.

31 b.d.a., Egypt and Syria to keep consulate relations: FM spokesperson, 7.07.2013, Ahram Online, http://english.ahram.org.eg/NewsContent/1/64/75951/Egypt/Politics-/Egypt-andSyria-to-keep-consulate-relations-FM-spo.aspx.

32 b.d.a., EgyptAir suspends flights to Syria, again, 16.12.2012, Ahram Online, http:// english.ahram.org.eg/NewsContent/3/12/60642/Business/Economy/EgyptAir-suspendsflights-to-Syria,-again.aspx.

33 b.d.a., More than 100,000 Syrian refugees in Egypt, 30.01.2013, Ahram Online, http:// english.ahram.org.eg/NewsContent/2/8/63677/World/Region/More-than-,-Syrian-refugeesin-Egypt.aspx. 
Reagując na nowe okoliczności Kair zaostrzał swój kurs wobec Damaszku. 15 czerwca 2013 r. w Kairze odbył się wiec, podczas którego Muhammad Mursi ogłosił zerwanie stosunków dyplomatycznych z Syrią ${ }^{34}$. Od tego czasu, wbrew wcześniejszym deklaracjom, Egipt zaczął otwarcie wzywać do wojny przeciwko Baszszarowi al-Asadowi i zachęcał inne państwa do uchwalenia odpowiednich rezolucji w tej sprawie tj. utworzenia strefy zakazu lotów oraz interwencji zewnętrznej ${ }^{35}$. Zapowiadało się zatem, że Egipt w znacznie większym stopniu zaangażuje się w wojnę przeciwko Syrii, jednak już dwa tygodnie później, w Egipcie dokonał się przewrót wojskowy, który zakończył rządy Bractwa Muzułmańskiego w tym kraju.

Trwające półtora roku rządy Bractwa Muzułmańskiego w Egipcie skutkowały zmianami w relacjach pomiędzy tym państwem a Syrią. Opowiedzenie się po stronie rebeliantów oraz przeciwko rządowi syryjskiemu umieściło Egipt w szeregu wrogów Syrii. Gdy pod koniec czerwca 2013 r. w Egipcie nastąpiła kolejna zmiana władzy, powstał szereg nowych okoliczności, które mogły doprowadzić do kolejnej reorientacji stosunków obu państw.

\section{Powrót rządów wojskowych w Egipcie i eskalacja wojny w Syrii}

Na początku 2013 r. w Egipcie doszło do wojskowego zamachu stanu. Grupa oficerów na czele z generałem Abd al-Fattahem as-Sisim dokonała przewrotu odsuwając od władzy Bractwo Muzułmańskie. Organizacja została zdelegalizowana, a jej członkowie poddani represjom. Ponieważ rządy islamistów w Egipcie warunkowały regres i zerwanie relacji z Syrią, a Muhammad Mursi był jednym z głośniejszych krytyków Baszszara al-Asada, to zmiana władzy stworzyła możliwość naprawienia tych relacji. Już w pierwszych tygodniach po odsunięciu Bractwa od władzy rozpoczęły się gesty dobrej woli obu państw względem siebie. Prezydent Syrii Baszszar al-Asad stwierdził, że obalenie Bractwa Muzułmańskiego w Egipcie to klęska politycznego islamu, co stanowiło jednocześnie poparcie dla nowych

34 b.d.a., Mursi cuts Egypt's Syria ties, 16.06.2013, News24, https://m.news24.com/Africa/ News/Mursi-cuts-Egypts-Syria-ties-20130616-2.

35 H. Mourad, Egypt and the Syrian conflict, 5.03.2014, Ahram Online, http://english. ahram.org.eg/NewsContent/4/0/95928/Opinion/-Egypt-and-the-Syrian-conflict.aspx. 
władz $^{36}$. Te z kolei jeszcze w lipcu 2013 r. zadeklarowały chęć odnowienia relacji z Syrią ${ }^{37}$.

Jednak mimo porzucenia wrogiej retoryki i pojawienia się gestów dobrej woli, Egipt nie podjął działań na rzecz szybkiej normalizacji relacji z Syrią. Mogły o tym zdecydować naciski sił zewnętrznych (będzie o tym mowa w części czwartej) lub czynniki pragmatyczne. W drugiej połowie 2013 r. już około połowa terytorium Syrii była pod kontrolą rebeliantów. Egipt mógł się spodziewać, że w kolejnych latach nastąpi zmiana władzy w Damaszku. W związku z tym Kair przyjął postawę bierną i wyczekującą na dalszy rozwój wydarzeń w Syrii, jednocześnie zachowując neutralność wobec stron konfliktu ${ }^{38}$.

Sytuacja zaczęła ulegać zmianie w 2014 r., gdy coraz większą aktywność zaczęły wykazywać ekstremistyczne organizacje muzułmańskie. W czerwcu i lipcu tego roku bojownicy tych ekstremistycznych organizacji opanowali znaczne obszary Syrii oraz Iraku, a ich przywódca Abu Bakr al-Bagdadi ogłosił powstanie kalifatu - Państwa Islamskiego (Islamic State). Tymczasem w listopadzie 2014 r. na fali popularności IS wśród ekstremistów muzułmańskich, organizacja Ansar Beit al-Maqdis ogłosiła powstanie egipskiej komórki kalifatu na Półwyspie Synaj ${ }^{39}$. Dodatkowo Egipt stawał się coraz bardziej zdestabilizowany z powodu rosnącej fali zamachów terrorystycznych, nieograniczających się jedynie do Półwyspu Synaj. W nowych okolicznościach zarówno Egipt jak i Syria zmagały się z problemem terroryzmu ze strony radykalnych organizacji muzułmańskich. Był to czynnik, który wpłynął na zbliżenie obu państw. Zwłaszcza, że konflikt syryjski zaczął pociągać za sobą exodus ludności z tego kraju. Jednym z odbiorców fali uchodźców był Egipt, w którym w połowie

36 b.d.a., Syria's Assad says political Islam being defeated in Egypt, 3.07.2013, Ahram Online, http://english.ahram.org.eg/NewsContent/1/64/75641/Egypt/Politics-/Syrias-Assadsays-political-Islam-being-defeated-i.aspx.

37 b.d.a., Egypt and Syria to keep consulate relations: FM spokesperson, 7.07.2013, Ahram Online, http://english.ahram.org.eg/NewsContent/1/64/75951/Egypt/Politics-/Egypt-andSyria-to-keep-consulate-relations-FM-spo.aspx.

38 O. Kessler, Egypt Picks Sides in the Syrian War, 12.02.2017, Foreign Affairs, https://www. foreignaffairs.com/articles/syria/2017-02-12/egypt-picks-sides-syrian-war?amp.

39 D. Kirkpatrick, Secret Alliance: Israel Carries Out Airstrikes in Egypt, With Cairo's O.K., 3.02.2018, The New York Times, https://www.nytimes.com/2018/02/03/world/middleeast/ israel-airstrikes-sinai-egypt.html. 
października 2013 r. zarejestrowanych było 123296 osób ${ }^{40}$. Według izraelskiego dziennika Haaretz prezydent as-Sisi obawiał się, że rozpad Syrii jako konsekwencja upadku prezydenta al-Asada może uderzyć w bezpieczeństwo Egiptu ${ }^{41}$. Zwłaszcza, że opozycja syryjska nie była skonsolidowana i od początku w kręgach rebelianckich dochodziło do podziałów, a następnie do walk o wpływy. Poza tym największe wpływy wśród opozycji syryjskiej zyskały Państwo Islamskie, Bractwo Muzułmańskie i al-Kaida - organizacje wrogie również Egiptowi.

Od tej pory dla Egiptu sojusznikiem było każde państwo zmagające się z ekstremizmem muzułmańskim. Prezydent as-Sisi otwarcie przyznał, że Baszszar al-Asad jest częścią politycznego rozwiązania konfliktu syryjskiego ${ }^{42}$. Opinii tej nie podzielały ani Stany Zjednoczone ani wrogie Syrii państwa regionu. Ponadto według Middle East Monitor rozpoczęły się spotkania szefów wywiadów Egiptu i Syrii ${ }^{43}$. Z kolei Syrian Arab News Agency zaczęła akcentować polepszenie wzajemnych relacji za sprawą odbywających się coraz częściej spotkań delegacji obu krajów, na których omawiano kwestie ekonomiczne, polityczne i kulturowe ${ }^{44}$.

Chęć polepszenia przez Egipt relacji z Syrią można było zauważyć również na arenie międzynarodowej. Prezydent as-Sisi nie tylko porzucił agresywną retorykę stosowaną przez poprzednika, ale również zaczął wspierać Syrię w konkretnych sprawach. Gdy wojska syryjskie pod koniec 2016 r. podjęły próbę odbicia Aleppo, sprawą zajęła się Rada Bezpieczeństwa ONZ. Egipt jako jej niestały członek w latach 2016-2017 nie popierał inicjatyw amerykańsko-brytyjsko-francuskich domagających się całkowitego wstrzymania operacji oraz dążył do porozumienia jak największej

40 b.d.a., Amnesty says Egypt should stop arresting, deporting Syrian refugees, 17.10.2013, Ahram Online, http://english.ahram.org.eg/NewsContent/1/64/84133/Egypt/Politics-/ Amnesty-says-Egypt-should-stop-arresting,-deportin .aspx.

41 Z. Bar'el, In Blow to Iran, Egypt Becomes Surprise New Player in Syria, 21.08.2017, Haaretz, https://www.haaretz.com/amp/middle-east-news/syria/in-blow-to-iran-egyptbecomes-surprise-new-player-in-syria-1.5444424.

42 b.d.a., Sisi secures Israel's interests in Syria, 24.08.2017, Middle East Monitor, https://www. middleeastmonitor.com/20170824-sisi-secures-israels-interests-in-syria/amp/.

43 Ibidem.

44 M. Dayoub, Egyptian delegation visits Syrian consulate to announce solidarity with Syria, 25.02.2018, Syrian Arab News Agency, https://sana.sy/en/?p=128613, R. Jazaeri, SyrianEgyptian cultural meeting calls for enhancing bilateral cooperation, 6.02.2018, Syrian Arab News Agency, https://sana.sy/en/?p=126471. 
liczby członków Rady ${ }^{45}$. Z kolei gdy w kwietniu 2017 r. Zachód oskarżył Syrię o przeprowadzenie ataku chemicznego w Khan Sheikhun (w prowincji Idlib) i przygotował uchwałę potępiającą rząd syryjski w Radzie Bezpieczeństwa ONZ, Egipt wstrzymał się od głosu akcentując jednocześnie bezstronność i potrzebę usunięcia całej broni masowego rażenia z Bliskiego Wschodu ${ }^{46}$.

Również podejście Egiptu do kwestii zawieszenia Syrii w Lidze Państw Arabskich zaczęło ulegać zmianie. O ile pod koniec 2011 r. Egipt poparł wniosek o zawieszenie Syrii, prezydent as-Sisi zmienił optykę Egiptu i w tej sprawie. Przyłączył się do grona państw wzywających do odwieszenia Syrii $^{47}$. Według informacji na portalu al-Masdar w lutym 2017 r. Komisja ds. Arabskich w egipskim parlamencie przygotowała uchwałę wzywającą państwa arabskie do przywrócenia Syrii w prawach członka ${ }^{48}$. Przeciwne tej inicjatywnie pozostały wrogie Syrii naftowe monarchie Zatoki Perskiej, a sama Syria odrzuciła ideę powrotu do organizacji uznając ją za martwą oraz sterowaną przez m.in. Katar będący marionetką Zachodu.

Zastanawiający jest również brak odnowienia stosunków dyplomatycznych pomiędzy Egiptem a Syrią mimo wzajemnej deklaracji o potrzebie takiego procesu. Ponadto wciąż zawieszona jest komunikacja lotnicza pomiędzy oboma krajami. Stan taki trwał pięć lat po dojściu do władzy w Egipcie prezydenta as-Sisiego. Dotychczas nie odbyło się również spotkanie na szczycie prezydentów obu krajów, które pozwoliłoby uznać, że Egipt legitymizuje prezydenta Baszszara al-Asada jako przywódcę Syrii.

45 b.d.a., Egypt favoured more consultations on 'vetoed' Aleppo's resolution: FM, 6.12.2016, Ahram Online, http://english.ahram.org.eg/NewsContent/1/64/251471/Egypt/Politics-/ Egypt-favoured-more-consultations-on-vetoed-Aleppo\%20.aspx.

46 M.Aziz, Egypt says polarisation in UN over Idlib attack hurts Syrian people: Foreign ministry, 6.04.2017, Ahram Online, http://english.ahram.org.eg/NewsWorldCup/2018/262437. aspx.

47 O ile w 2011 r. przeciwko zawieszeniu Syrii były tylko Liban i Jemen, a Irak się wstrzymał, o tyle w 2017 r. za powrotem Syrii do organizacji były: Algieria, Egipt, Irak, Liban i Tunezja, zob. więcej: b.d.a., In Advance Of Arab League Summit In Jordan, Calls In Arab Countries To Reinstate Syria's League Membership; Syrian Writers Reject Calls For Reinstatement, Saying Syria Will Return Only If Arab League Apologizes To It, 23.03.2017, Memri, https://www.memri. org/reports/advance-arab-league-summit-jordan-calls-arab-countries-reinstate-syriasleague-membership.

48 Z. Adra, Egyptian parliament calls for Syria's return to Arab League, 14.02.2017, AlMasdar News, https://www.almasdarnews.com/article/egyptian-parliament-calls-syriasreturn-arab-league/. 
Mimo wszystko wg Syryjskiej Agencji Prasowej, we wrześniu 2017 r. Egipt rozpoczął działania na rzecz unieważnienia decyzji byłego prezydenta Mursiego o zerwaniu stosunków dyplomatycznych ${ }^{49}$.

Mimo, że do 2018 r. stosunki Egiptu i Syrii nie zostały w pełni znormalizowane oraz nie odbyło się spotkanie na szczycie głów obu państw, nie ulega wątpliwości, że w okresie rządów prezydenta as-Sisiego w Egipcie wzajemne relacje znacznie się polepszyły. Zmianie uległa retoryka pomiędzy przedstawicielami władz obu państw, jak również rozpoczęto spotkania delegacji. Łącząca była kwestia walki z terroryzmem, a Egipt w pewien sposób wspierał Syrię na arenie międzynarodowej. Właśnie kwestie międzynarodowe, a mianowicie wpływ aktorów zewnętrznych miał znaczący wpływ na kształtowanie relacji obu państw po 2011, a zwłaszcza po 2013 r.

\section{Wpływ aktorów trzecich}

Stosunki Egiptu i Syrii po 2011 r. kształtowane były nie tylko poprzez relacje bilateralne ale również, a może i przede wszystkim, przez wpływy sił zewnętrznych. Do najważniejszych aktorów wpływających po 2011 r. na relacje obu państw należą państwa regionu - Arabia Saudyjska, Iran, Izrael, Katar i Turcja, organizacje pozapaństwowe - Hezbollah oraz sunnickie organizacje ekstremistyczne, a także mocarstwa światowe - Rosja i Stany Zjednoczone. W niniejszym opracowaniu zostały one podzielone na dwie kategorie dzielące się na dwie podkategorie:

1) Aktorzy hamujący rozwój relacji Egiptu i Syrii

1a) Państwa pozostające w dobrych lub poprawnych relacjach z Egiptem, a jednocześnie skonfliktowane z Syrią - Arabia Saudyjska, Stany Zjednoczone, Izrael

1b) Podmioty będące sojusznikami Syrii, ale skonfliktowane z Egiptem - Iran, Hezbollah

2) Aktorzy zbliżający oba państwa

2a) Wspólni sojusznicy Egiptu i Syrii - Rosja

2b) Wspólni wrogowie obu państw - Katar, Turcja, Bractwo Muzułmańskie (po 2013 r.), Al-Kaida, IS.

49 M. al-Frieh, Two lawsuits filed in Egyptian court to restore Egyptian-Syrian relations, 10.09.2017, Syrian Arab News Agency, https://sana.sy/en/?p=113593. 
Sieć relacji determinująca relacje egipsko-syryjskie przedstawia poniższa grafika.

Rys. 1. Układ zależności wpływających na relacje egipsko-syryjskie po $2013 \mathrm{r}$.

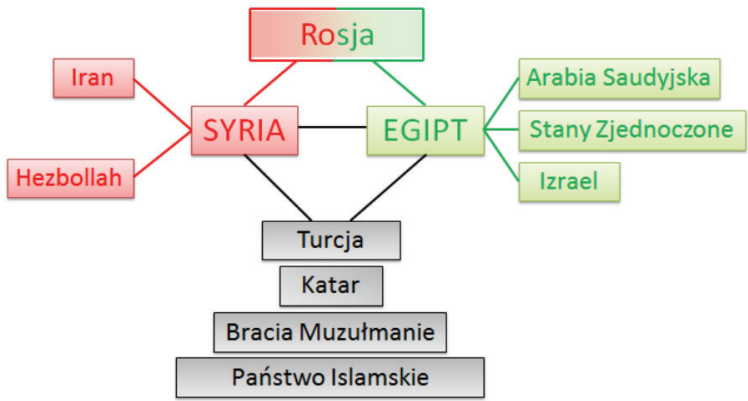

Źródło: Opracowanie własne.

Arabia Saudyjska była jednym z państw, które wywarły największy wpływ na relacje Egiptu i Syrii. Od początku konfliktu syryjskiego zaangażowała się we wspieranie rebeliantów, a więc w wojnę przeciwko siłom rządowym. Jednak Saudowie nie mieli dobrych układów również z Bractwem Muzułmańskim rządzącym Egiptem w latach 2012-2013. Bractwo współpracowało z Katarem, który był uważany przez Rijad za rywala, a ponadto mogło stanowić zagrożenie dla dynastii Saudów ${ }^{50}$. Gdy gen. as-Sisi przejął władzę, Egipt był zdestabilizowany i potrzebował wsparcia gospodarczego. Udzielili go Saudowie, w ten sposób wciągając kraj w orbitę swoich wpływów. W latach 2013-2017 pomoc Arabii Saudyjskiej dla Egiptu wyniosła 25 miliardów dolarów ${ }^{51}$. W zamian Kair musiał pełnić rolę sojusznika Rijadu w kwestiach regionalnych dotyczących m.in. Iranu, Jemenu i Syrii. Prawdopodobne jest zatem, że tak powolna normalizacja stosunków z Syrią, mimo czynionych deklaracji, to wynik oddziaływania Arabii Saudyjskiej.

Jednak Egipt również miał swoją rację stanu. Dla Arabii Saudyjskiej największym wrogiem był Iran, z kolei dla Egiptu były to radykalne organizacje muzułmańskie - IS, Al-Kaida i Bractwo Muzułmańskie. Na tym

50 F. Pichon, op.cit., s. 90.

51 O. Kessler, Egypt Picks Sides in the Syrian War, 12.02.2017, Foreign Affairs, https://www. foreignaffairs.com/articles/syria/2017-02-12/egypt-picks-sides-syrian-war?amp. 
polu Kairowi bliżej było do Damaszku niż do Rijadu. Jednak Saudowie nie aprobowali egipskich prób zbliżenia z Syrią. Gdy w październiku 2016 r. na forum Rady Bezpieczeństwa ONZ Egipt zademonstrował sprzeciw wobec zachodnich oraz saudyjskich działań ws. natarcia wojsk syryjskich na Aleppo, Arabia Saudyjska wstrzymała dostawy taniej ropy do Egiptu ${ }^{52}$.

Wkrótce na Bliskim Wschodzie rozpoczął się nowy proces, który mógł doprowadzić do większej swobody Egiptu w kwestii relacji z Syrią. W czerwcu 2017 r. rozpoczął się kryzys katarski. Dla Rijadu Douha stała się wrogiem, przeciwko któremu Królestwo chciało zmontować koalicję państw regionu. Rijad otrzymał wsparcie Kairu. Według izraelskiego dziennika Haaretz poparcie Egiptu ws. Kataru było Saudom bardziej potrzebne niż ws. Syrii ${ }^{53}$. Kryzys katarski nałożył się w czasie z osiąganiem sukcesów przez wojska rządowe w Syrii i odzyskaniem przez nich znacznych obszarów państwa. Stworzyło to dla Egiptu uwarunkowania do prowadzenia bardziej niezależnej polityki wobec Syrii, czego przejawem mogą być wspomniane wcześniej kroki na rzecz unormowania stosunków.

W znacznie mniejszym stopniu na relacje obu państw wpływają Stany Zjednoczone. Amerykanie od początku poparli rebelię w Syrii, a jednocześnie utrzymywali sojusz z Egiptem, zwłaszcza po dojściu do władzy as-Sisiego. Nowy prezydent nie mógł sobie pozwolić na otwarty sojusz z Syrią ani na inne działania krzewiące arabski nacjonalizm gdyż, jak uważa Fred Halliday, Egipt jest zbyt uzależniony od amerykańskiego wsparcia ${ }^{54}$. Polityka Stanów Zjednoczonych wobec Egiptu warunkowana jest przede wszystkim chęcią zabezpieczenia granic Izraela.

Izrael jest kolejnym państwem, do którego inaczej podchodzą Egipt i Syria. Egipt ma z Izraelem podpisany układ pokojowy, Syria z kolei nigdy nie podpisała podobnej umowy. Ponadto Egipt i Izrael współpracują w kwestii zwalczania terroryzmu na Półwyspie Synaj. Tymczasem Syria po 2011 r.

52 R. Ghosh, Collective Responsibility: Egyptian President Sisi's support for Assad is rooted in UN principles, 24.11.2016, The Times of India, https://blogs.timesofindia.indiatimes.com/ talkingturkey/collective-responsibility-egyptian-president-sisis-support-for-assad-is-rootedin-un-principles/.

53 Z. Bar'el, In Blow to Iran, Egypt Becomes Surprise New Player in Syria, 21.08.2017, Haaretz, https://www.haaretz.com/amp/middle-east-news/syria/in-blow-to-iran-egyptbecomes-surprise-new-player-in-syria-1.5444424.

54 F. Halliday, Bliski Wschód w stosunkach międzynarodowych, tłum. J. Tegnerowicz, Kraków 2009, s. 69. 
była wielokrotnie atakowana przez Izrael z powietrza. Egipt zdystansowany był również od sprawy palestyńskiej, tymczasem Syria dążyła do bycia orędownikiem Palestyńczyków w ich walce o niepodległość. Jednak Izrael w przeciwieństwie do Arabii Saudyjskiej oraz Stanów Zjednoczonych nie wywiera nacisków na Egipt celem zahamowania relacji tego państwa z Syrią.

Specyficzny wpływ na relacje obu aktorów ma Iran. Islamska Republika od początku kryzysu syryjskiego popierała prezydenta Baszszara al-Asada. Jednocześnie stała się największym wrogiem Arabii Saudyjskiej, od której Egipt po 2013 r. był zależny. Zatem podejście obu państw do Iranu było różne. Nie był to jednak czynnik jednoznacznie negatywnie wpływający na relacje obu państw. Iran wedle zasady „dziel i rządź” proponował włączenie w prace nad rozwiązaniem konfliktu syryjskiego Egiptu jako najludniejszego kraju arabskiego i sunnickiego ${ }^{55}$. Z drugiej zaś strony Egipt chcąc konkurować z Iranem o wpływy w Syrii mógłby w przyszłości zaangażować się w odbudowę tego państwa oraz zacieśnienie relacji. Jednak aby taka idea miała szansę na realizację, Egipt musiałby zainwestować odpowiednie środki, o co byłoby trudno bez aprobaty Arabii Saudyjskiej.

Podobnie jak Iran, również Hezbollah wywoływał różne podejście obu państw. Partia Boga jako niepaństwowy aktor zajmujący ważne miejsce w bliskowschodnim układzie sił jest szyicką organizacją będącą w ścisłym sojuszu z Iranem, Podobnie jak Iran, Hezbollah zaangażował się po stronie sił rządowych będąc jednym z bliższych sojuszników Damaszku. Z kolei dla Kairu Hezbollah był wrogiem zarówno w okresie rządów Hosniego Mubaraka, Muhammada Mursiego jak i Abd al-Fattaha as-Sisiego.

Pozytywnie na relacje egipsko-syryjskie działa wspólny sojusznik obu państw - Federacja Rosyjska. Syria miała z nią tradycyjnie dobre stosunki sięgające czasów ZSRR, z kolei stosunki egipsko-rosyjskie rozwinęły się w znacznym stopniu po dojściu do władzy Abd al-Fattaha as-Sisiego. Rosja zaangażowała środki militarne i polityczne, aby zapewnić wojskom rządowym Syrii zwycięstwo. Z kolei Egipt poparł te działania. Kair i Moskwa również zacieśniały współpracę na polu politycznym i wojskowym ${ }^{56}$. Po-

55 R. Ramesh, Iran 'wanted Egypt at Syria talks' as Middle Eastern alliances shift, 20.10.2016, The Guardian, https://amp.theguardian.com/world/2016/oct/20/iran-egypt-syriatalks-middle-eastern-alliances-shift.

56 Chodzi przede wszystkim o dostawę rosyjskiego uzbrojenia, które zastępowało zmniejszające się wsparcie amerykańskie, jak również o wspólne manewry i ćwiczenia wojskowe, 
nadto Rosja zachęcała Egipt do zaangażowania ws. uregulowania konfliktu syryjskiego ${ }^{57}$. Wszystkie te działania Rosji miały na celu nie tylko pozyskanie sojusznika, ale również wyciągnięcie Egiptu z orbity wpływów Stanów Zjednoczonych oraz Arabii Saudyjskiej. W tym celu zbliżenie egipsko-syryjskie jest dla Rosji użyteczne i w najbliższym czasie można spodziewać się większej ilości działań podjętych w tym celu. Z kolei rosyjskie wsparcie dla Egiptu oddala wizję uzależnienia tego kraju od pomocy saudyjskiej i amerykańskiej. Większa niezależność Egiptu niewątpliwie skutkowałaby przyspieszeniem procesu normalizacji stosunków z Syrią.

Podobnie jak wspólni sojusznicy tak i wspólni wrogowie mogą warunkować zbliżenie obu aktorów. Wpływ radykalnych organizacji muzułmańskich takich jak Państwo Islamskie, Al-Kaida, i Bractwo Muzułmańskie na poprawę relacji egipsko-syryjskich został omówiony w części trzeciej. Rola Kataru w relacjach obu państw przyjmowała różne oblicze. W okresie gdy Egipt rządzony był przez Bractwo Muzułmańskie, Katar był sojusznikiem tego państwa i w latach 2012-2013 przeznaczył na wsparcie dla niego 8 mld dolarów ${ }^{58}$. Po zmianie uwarunkowań w 2013 r. Katar przestał być sojusznikiem Egiptu, ponieważ wspierane przez Douhę Bractwo stało się jednym z większych wrogów Kairu. Zatem Katar po 2013 r. był wrogiem zarówno dla Egiptu jak i dla Syrii.

Podobnie jak w przypadku Kataru, także rola Turcji uległa zmianie po 2011 r. W okresie rządów Bractwa Muzułmańskiego w Egipcie, prezydent Turcji Recep Tayyip Erdogan zaczął patronować organizacjom islamistycznym, co zbliżało do siebie oba państwa, a jednocześnie konfliktowało je z Syrią. Tak jak wobec Kataru tak i wobec Turcji zmieniło się stanowisko nowych egipskich władz po 2013 r. Z kolei władze tureckie tak jak potępiały syryjskiego prezydenta, tak zaczęły również krytykować nowe władze Egiptu ${ }^{59}$.

kontrakty gospodarcze oraz udostępnianie Rosji egipskich baz lotniczych i przestrzeni powietrznej. Zob więcej: A. Chibarirwe, Egypt Ditching America, Looking for New Allies, 16.03.2018, The Trumpet, https://www.thetrumpet.com/17028-egypt-ditching-america-looking-for-new-allies.

57 W. Rodkiewicz, Rosja: umacnianie wptywów w Egipcie, 13.12.2017, Ośrodek Studiów Wschodnich, https://www.osw.waw.pl/pl/publikacje/analizy/2017-12-13/rosja-umacnianiewplywow-w-egipcie.

58 S. Henderson, Gulf Aid To Egypt And U.S. Policy, b.d.w., Midan Masr, http://www. midanmasr.com/en/article.aspx?ArticleID=338.

59 O. Kessler, Egypt Picks Sides in the Syrian War, 12.02.2017, Foreign Affairs, https://www. foreignaffairs.com/articles/syria/2017-02-12/egypt-picks-sides-syrian-war?amp. 
Zaprezentowana sieć powiązań i zależności determinująca stosunki egipsko-syryjskie obejmuje wiele podmiotów jednak należy wyróżnić trzy z nich mające największy wpływ na kształtowanie się relacji Kairu i Damaszku. Są to: Arabia Saudyjska, Rosja i Stany Zjednoczone. To one starają się zarówno środkami ekonomicznymi jak i politycznymi wpłynąć na relacje tych państw. Z kolei organizacje ekstremistyczne warunkują wspólne cele obu państw, takie jak walka z terroryzmem oraz z destabilizacją. Pozostałe podmioty nie mają znaczącego wpływu na progresję bądź regresję relacji obu aktorów. Poza tym jak już zostało wspomniane, coraz więcej państw uznaje, że Baszszar al-Asad nie zostanie obalony i pozostanie u sterów władzy w Syrii. Stopniowo z zaangażowania przeciwko Syrii wycofują się Arabia Saudyjska oraz Stany Zjednoczone czyli podmioty, które hamują rozwój relacji egipsko-syryjskich. Z kolei w kolejnych latach prawdopodobnie utrzyma się w regionie zagrożenie terroryzmem i ekstremizmem muzułmańskim, który będzie wymierzony również w Egipt i Syrię. Oba powyższe czynniki mogą świadczyć o tym, że niezależnie od tempa, dojdzie do pełnej normalizacji stosunków obu państw.

\section{Konkluzje}

Egipt i Syria od ponad trzech i pół tysiąclecia łączy wspólna historia. Od tego czasu ziemie obydwu dzisiejszych państw wspólnie przechodziły przez procesy historyczne takie jak rozwój szlaków handlowych oraz ulegały podbojom perskim, greckim, rzymskim, bizantyjskim, arabskim. Następnie Egipt i Syria były pod panowaniem Mameluków, Turcji Osmańskiej i zachodnich mocarstw kolonialnych. Oba państwa krzewiły idee narodowo-wyzwoleńcze oraz panarabskie i socjalistyczne, w końcu wywalczając niepodległość i suwerenność. Mimo kwestii spornych, czasem prowadzących do zamrożenia relacji, pozostawały one w dobrych stosunkach do $2011 \mathrm{r}$. Tak zwana Arabska Wiosna dotknęła oba państwa i wpłynęła znacząco na relacje pomiędzy nimi. Procesy rewolucyjne wyniosły do władzy w Egipcie Bractwo Muzułmańskie, które było jednocześnie zaangażowane w konflikt syryjski przeciwko siłom rządowym. Oznaczało to regres w stosunkach obu państw, którego apogeum przypadło na połowę 2013 r. kiedy Egipt zerwał stosunki dyplomatyczne z Syrią. Jednak wkrótce potem islamiści zostali od- 
sunięci od władzy przez wojsko. Rozpoczął się powolny proces ocieplania relacji wzajemnych. Nie podjęto jednak konkretnych działań w tym celu, takich jak pełne odnowienie stosunków dyplomatycznych. Egipt początkowo starał się być neutralny wobec konfliktu w Syrii. Mimo zmiany retoryki na pozytywną, spotkań delegacji, wspólnego podejścia do kwestii walki z destabilizującym oba kraje terroryzmem i w końcu poparciem przez Egipt dla inicjatywy odwieszenia Syrii w Lidze Państw Arabskich, naciski sił zewnętrznych utrudniały pełną normalizację relacji, przy czym to głównie Egipt pozostawał pod presją. Wywierały ją Arabia Saudyjska i Stany Zjednoczone wspomagające Kair finansowo, a jednocześnie zaangażowane przeciwko Syrii. Z kolei Rosja prowadziła działania mające na celu odciągnięcie Egiptu od osi saudyjsko-amerykańskiej, co pozwoliłoby na większe zbliżenie z Syrią. Mniejszy pozostaje wpływ innych aktorów, których podejście różnicuje obydwa państwa, tj. Iranu, Izraela, a w latach 2012-2013 Kataru i Turcji; oraz będących wspólnymi wrogami obu państw Kataru, Turcji (po 2013 r.). Ponieważ państwa skonfliktowane z Syrią, a wspomagające Egipt (Arabia Saudyjska, Stany Zjednoczone), w coraz mniejszym stopniu angażują się w konflikt syryjski, a problem terroryzmu zagrażającego Egiptowi i Syrii pozostanie, nasuwa się wniosek, że w niedalekiej przyszłości dojdzie do pełnej normalizacji stosunków obu państw. Mimo, że procesy tzw. Arabskiej Wiosny doprowadziły tytułowych aktorów do destabilizacji i osłabienia gospodarki, to wciąż stanowić one będą newralgiczny punkt Bliskiego Wschodu, jednego z najbardziej kluczowych i zarazem zapalnych regionów świata. Poza tym stan stosunków egipsko-syryjskich budzi zainteresowanie i determinuje działania innych aktorów, co udowadnia, że relacje obu tych państw pełnią ważną rolę w regionie.

\section{Bibliografia}

\section{Publikacje książkowe}

Dziekan M., Dzieje kultury arabskiej, Warszawa 2008.

Fryzeł T., Liga Państw Arabskich, Warszawa 1981.

Fyderek Ł., Pretorianie i technokraci w reżimie politycznym Syrii, Kraków 2011. 
Halliday F., Bliski Wschód w stosunkach międzynarodowych, tłum. J. Tegnerowicz, Kraków 2009.

Hourani A., Historia Arabów, tłum. oprac. zbior. Gdańsk 1995.

Jankowski J., Nasser's Egypt. Arab nationalism and the United Arab Republic, Londyn 2002.

Kissinger H., Porzadek światowy, tłum. M. Antosiewicz, Wołowiec 2016.

Niedziela Sz., Konflikty i napięcia w świecie arabskim, Warszawa 2012.

Ożarowski R., Ideologia na Bliskim Wschodzie, Gdańsk 2006.

As-Sajjid Marsot A.L., Historia Egiptu. Od podboju arabskiego do czasów współczesnych, tłum. Z. Landowski, Warszawa 2009.

Pichon F., Syria. Porażka strategii Zachodu, tłum. G. Majcher, Warszawa 2015.

Stępniewska-Holzer B., Muhammad Ali. Narodziny nowoczesnego Państwa Egipskiego, Wrocław 1978.

Zdanowski J., Bliski Wschód 2011: bunt czy rewolucja?, Kraków 2011.

Żebrowski J., Dzieje Syrii. Od czasów najdawniejszych do wspótczesności, Warszawa 2006.

\section{Artykuły internetowe}

Adra Z., Egyptian parliament calls for Syria's return to Arab League, 14.02.2017, Al-Masdar News, https://www.almasdarnews.com/article/egyptian-parliament-calls-syrias-return-arab-league/.

Bakr A., Egypt's Mursi says opposes foreign intervention in Syria, 26.09.2012, Reuters, https://mobile.reuters.com/article/amp/idUSBRE88P1BC20120926.

Bar'el Z., In Blow to Iran, Egypt Becomes Surprise New Player in Syria, 21.08.2017, Haaretz, https://www.haaretz.com/amp/middle-eastnews/syria/in-blow-to-iran-egypt-becomes-surprise-new-player-in-syria-1.5444424.

Chibarirwe A., Egypt Ditching America, Looking for New Allies, 16.03.2018, The Trumpet, https://www.thetrumpet.com/17028-egypt-ditching-america-looking-for-new-allies.

Dayoub M., Egyptian delegation visits Syrian consulate to announce solidarity with Syria, 25.02.2018, Syrian Arab News Agency, https://sana. sy/en/?p=128613. 
Al-Frieh M., Two lawsuits filed in Egyptian court to restore Egyptian-Syrian relations, 10.09.2017, Syrian Arab News Agency, https://sana.sy/ en/?p=113593.

Ghosh R., Collective Responsibility: Egyptian President Sisi's support for Assad is rooted in UN principles, 24.11.2016, The Times of India, https://blogs.timesofindia.indiatimes.com/talkingturkey/collective-responsibility-egyptian-president-sisis-support-for-assad-is-rooted-in-un-principles/.

Henderson S., Gulf Aid To Egypt And U.S. Policy, b.d.w., Midan Masr, http://www.midanmasr.com/en/article.aspx?ArticleID=338.

Jazaeri R., Syrian-Egyptian cultural meeting calls for enhancing bilateral cooperation, 6.02.2018, Syrian Arab News Agency, https://sana.sy/ en/?p=126471.

Kessler O., Egypt Picks Sides in the Syrian War, 12.02.2017, Foreign Affairs, https://www.foreignaffairs.com/articles/syria/2017-02-12/egypt-picks-sides-syrian-war?amp.

Kirkpatrick D., Secret Alliance: Israel Carries Out Airstrikes in Egypt, With Cairo's O.K., 3.02.2018, The New York Times, https://www.nytimes. com/2018/02/03/world/middleeast/israel-airstrikes-sinai-egypt.html.

Mourad H., Egypt and the Syrian conflict, 5.03.2014, Ahram Online, http:// english.ahram.org.eg/NewsContent/4/0/95928/Opinion/-Egypt-and-the-Syrian-conflict.aspx.

Ramesh R., Iran 'wanted Egypt at Syria talks' as Middle Eastern alliances shift, 20.10.2016, The Guardian, https://amp.theguardian.com/ world/2016/oct/20/iran-egypt-syria-talks-middle-eastern-alliances-shift.

Rodkiewicz W., Rosja: umacnianie wpływów w Egipcie, 13.12.2017, Ośrodek Studiów Wschodnich, https://www.osw.waw.pl/pl/publikacje/analizy/2017-12-13/rosja-umacnianie-wplywow-w-egipcie.

Zain H., Syrian, Egyptian Journalists agree on enhancing cooperation, 4.02.2018, Syrian Arab News Agency, https://sana.sy/en/?p=126313.

b.d.a., Amnesty says Egypt should stop arresting, deporting Syrian refugees, 17.10.2013, Ahram Online, http://english.ahram.org.eg/NewsContent/1/64/84133/Egypt/Politics-/Amnesty-says-Egypt-should-stop-arresting,-deportin.aspx. 
b.d.a., Egypt and Syria to keep consulate relations: FM spokesperson, 7.07.2013, Ahram Online, http://english.ahram.org.eg/NewsContent/1/64/75951/Egypt/Politics-/Egypt-and-Syria-to-keep-consulate-relations-FM-spo.aspx.

b.d.a., Egypt favoured more consultations on 'vetoed' Aleppo's resolution: FM, 6.12.2016, Ahram Online, http://english.ahram.org.eg/NewsContent/1/64/251471/Egypt/Politics-/Egypt-favoured-more-consultations-on-vetoed-Aleppo\%20.aspx.

b.d.a., In Advance Of Arab League Summit In Jordan, Calls In Arab Countries To Reinstate Syria's League Membership; Syrian Writers Reject Calls For Reinstatement, Saying Syria Will Return Only If Arab League Apologizes To It, 23.03.2017, Memri https://www.memri.org/reports/ advance-arab-league-summit-jordan-calls-arab-countries-reinstate-syrias-league-membership.

b.d.a., More than 100,000 Syrian refugees in Egypt, 30.01.2013, Ahram Online, http://english.ahram.org.eg/NewsContent/2/8/63677/World/Region/More-than-,-Syrian-refugees-in-Egypt.aspx.

b.d.a., Mursi cuts Egypt's Syria ties, 16.06.2013, News24, https://m.news24. com/Africa/News/Mursi-cuts-Egypts-Syria-ties-20130616-2.

b.d.a., Sisi secures Israel's interests in Syria, 24.08.2017, Middle East Monitor, https://www.middleeastmonitor.com/20170824-sisi-secures-israels-interests-in-syria/amp/.

b.d.a., Syria's Assad says political Islam being defeated in Egypt, 3.07.2013, Ahram Online, http://english.ahram.org.eg/NewsContent/1/64/75641/Egypt/Politics-/Syrias-Assad-says-political-Islam-being-defeated-i.aspx.

b.d.a., UN and partners launch major aid plans for Syria and region, UNHCR The UN Refugee Agency, http://www.unhcr.org/news/ press/2014/12/54929c676/un-partners-launch-major-aid-plans-syria-region.html. 


\section{Egyptian-Syrian relations after 2011}

\section{Summary}

Egypt and Syria have been important actors in the Middle East, a region of considerable geostrategic importance. This article analyses relations between the two countries after 2011 in the context of events related to the so-called Arab Spring. The first part of the study describes the common path Egypt and Syria took over the past millennia, which explains the significance of their mutual relations. In the section that follows, the author shows the destructive impact of processes related to the Arab Spring on relations between these countries, most notably the eruption of the Syrian conflict and the takeover of power in Egypt by the Muslim Brotherhood. Next, the article describes the impact of the fall of Islamists in Egypt in 2013. Although since then relations between the two countries have ceased to be hostile, efforts to repair them remain slow. The author argues that the reasons for this delay could be attributed to the pressures exercised by external actors.

Keywords: Egypt, Syria, Middle East, Arab Spring, Egyptian-Syrian relations, Muslim Brotherhood

\section{Отношения эгипско-сирийское после 2011 гоАа}

\section{Резюме}

Египет и Сирия от наА три тысячелетия преАставляют собой важная точка в ближневосточном регионе быть кАючевое значение гэостратэгичнэ как в очередных исторических эпохах как и теперь. Этот статья Аемонстрирует анализ сообщения среди оба государств после 2011 г. в контексте событий связать с т. наз. Арабскую Весной. Первая часть разработки описывает общую Аорогу Египта и Сирии за очередные тысячелетия что объясняет значение сообщению оба актеров. В более Аалекой части автор убежАает в разрушительной роли процессов связанных с т. наз. Арабскую Весной в скмадываться отношений межАу этими государствами, что у связи с начатием сирийского конфликта и принять владения Египтом Мусульманскую Компанией. В слеАующий очереАности статья описывает влияние отоАВиновения исламистов от владения Египтом на связи этого государства со Сирией. Несмотря на то, что сообщения оба государств перестают быть враждебное, их полная нормализация не наступает. Автор убежАает, что - это эффект Аействия внешних актеров. Взволнованные вопросы в этот 
статье преАстав яют собой попытку понять обусловленность сообщения государств преАставАяющих собой важную часть Ближнего Восток, быть оАним из наиболее невралгических регионов на карте мира.

Кмючевые слова: Египет, Сирия, Ближний Восток, Арабска Вёсна, Стосунки эгипско-сырыйске, Брацтво Музумманьске, Госни Мубарак, Башшар аль-АсаА, МугаммаА Мурси, АбА аль-Фаттаг ас-Сиси, Скутки Арабскей Вёсны

\author{
mgr Jacek Małecki \\ Wydział Nauk Społecznych \\ Uniwersytet Gdański \\ ul. Jana Bażyńskiego 4 \\ 80-309 Gdańsk \\ e-mail: jacek.malecki@onet.com.pl
}

